\title{
Article
}

\section{Morphology and phylogeny of Mycopepon}

\section{Liu $\mathrm{LL}^{1,2}$, Long $\mathrm{QD}^{1,3}$, Kang $\mathrm{JC}^{4}$, Zhang $\mathrm{X}^{1,3}$, Hyde $\mathrm{KD}^{5}$, Shen $\mathrm{XC}^{1,3 *}$ and $\mathrm{Li}$ $\mathbf{Q R}^{1,3 *}$}

${ }^{1}$ State Key Laboratory of Functions and Applications of Medicinal Plants, Guizhou Medical University, Guiyang 550004, People's Republic of China

${ }^{2}$ Immune Cells and Antibody Engineering Research Center of Guizhou Province/ Key Laboratory of Biology and Medical Engineering, Guizhou Medical University, Guiyang 550004, People's Republic of China

${ }^{3}$ The Key Lab of Optimal Utilization of Natural Medicine Resources, School of Pharmaceutical Sciences, Guizhou Medical University, University Town, Guian New District, Guizhou 550025, People's Republic of China

${ }^{4}$ The Engineering and Research Center for Southwest Bio-Pharmaceutical Resources of National Education Ministry of China, 3Guizhou University Guiyang 550025, People's Republic of China

${ }^{5}$ Center of Excellence in Fungal Research, Mae Fah Luang University, Chiang Rai 57100, Thailand

Liu LL, Long QD, Kang JC, Zhang X, Hyde KD, Shen XC, Li QR 2018 - Morphology, and phylogeny of Mycopepon. Mycosphere 9(4), 779-789, Doi 10.5943/mycosphere/9/4/6

\begin{abstract}
Two species similar to Mycopepon were found on bamboo in Guizhou Province, China. These species are introduced as the new species Mycopepon bambusae M. fusoidisporus, based on their morphological characteristics and phylogenetic analyses of LSU and SSU sequences data in this paper. Descriptions and illustrations for both species are provided. Mycopepon smithii var. mexicanum is raised to specific rank as M. mexicanus stat. nov. Mycopepon bambusae differs from M. smithii and M. mexicanus by its narrower ascospores $(45-61.5 \times 6.5-8.5 \mu \mathrm{m})$. Mycopepon fusoidisporus has the unique features of 1-septate, dark brown, wider, ellipsoid-fusiform ascospores $(45.5-57.5 \times 11.5-23.5 \mu \mathrm{m})$. Based on a combined SSU and LSU sequence data, the phylogenetic results indicate that Mycopepon falls in Astrosphaeriellaceae.
\end{abstract}

Key words -2 new species - Astrosphaeriellaceae - Dothideomycetes - Pleosporales - taxonomy

\section{Introduction}

The fungi on bamboo are a phylogenetically diverse group with many genera only known from this host (Hyde et al. 2002, Dai et al. 2016). Several of the genera are poorly known (e.g. Linearistroma, Mycopepon, Shiraia) and have rarely been collected (Boise 1987, Phookamsak et al. 2014, Dai et al. 2016). Mycopepon Boise was introduced by Boise (1987) with M. guianensis Boise (current name: M. smithii (Ellis \& Everh.) Boise) as the type species and is only known from the American continent (Wijayawardene et al. 2017). The genus is characterized by superficial ascostromata with multiple ascomata with eccentric papillae that fuse into a common central papilla, giving the overall appearance of a pumpkin. Mycopepon has been recorded from Mexico, Nicaragua and South America in French Guiana (Boise 1987, 1994). Five epithets are listed in Index Fungorum (2018). However, only one name [M. smithii (Ellis \& Everh.) Boise] is accepted in this genus (Index Fungorum 2018). Since Mycopepon lacks DNA sequence data, Mycopepon has been placed in Dothideomycetes genera incertae sedis (Boise 1987, Eriksson \& Hawksworth 1987, Wijayawardene et al. 2014, 2015, 2018). 
During an investigation of Xylariales in China, two mycopepon-like taxa were collected and examined. Based on morphology and molecular data, two new species, M. bambusae and $M$. fusoidisporus, were identified. On further study of the genus we proposed that the variety mexicanum of Mycopepon smithi should be raised to specific rank as M. mexicanus.

\section{Materials \& Methods}

\section{Isolates and morphology}

Materials were collected from Guizhou Province in China. The fungal material were placed in plastic bags with some silica gel desiccant and brought to the laboratory. All collection details were noted and material was examined within two months. Morphological examination followed the methods from Su et al. (2016), Liu et al. (2018). Materials were mounted in water and Melzer's iodine reagent. The characteristics of ascostromata were examined by using a stereomicroscope, and were photographed by a digital camera (BX41, Olympus; Ni Nikon). Morphological characteristics of the asci and ascospores were photographed using a digital camera fitted with the compound light microscopy ( $\mathrm{Ni}$ Nikon). All microphotographs were arranged using Adobe Photoshop CS6 and all measurements were made with Tarosoft ® image framework (v. 0.9.0.7). Single-spore isolations were carried out as described by Li et al. (2015). Cultures were grown in Petri-dishes on potato dextrose agar (PDA) at $20-25{ }^{\circ} \mathrm{C}$. The herbarium and living cultures are deposited in Guizhou Medical University (GMB) and Kunming Institute of Botany (KUN), Chinese Academy of Sciences.

\section{DNA extraction, PCR and sequencing}

Total DNA products were extracted from fresh fungal mycelia by using a BIOMIGA Fungus Genomic DNA Extraction Kit (GD2416) (Wijayawardene et al. 2013). The amplification of the 28S large subunit (LSU) was carried out using LROR and LR5 (Vilgalys \& Hester 1990) primers. Primer pairs NS1 and NS4 designed by White et al. (1990) were applied to amplify a region of the 18S small subunit rDNA. Primer pairs ITS5 and ITS4, were used to amplify ITS region (White et al. 1990). According to $\mathrm{Su}$ et al. (2016), the amplification conditions were carried out via PCR reactions in $25 \mu \mathrm{L}$ volume (double distilled water 9.5 $\mu \mathrm{L}$, PCR Master Mix 12.5 $\mu \mathrm{L}, 1 \mu \mathrm{L}$ of each primer, $1 \mu \mathrm{L}$ template DNA). Amplified PCR fragments were sequenced by Sino Geno Max, Beijing, China. The sequence data were deposited in GenBank.

\section{Sequence alignment and phylogenetic analyses}

All strains for phylogenetic analyses chosen based on published literature (Hyde et al. 2013, Phookamsak et al. 2015) were marked in RAxML tree (Fig. 1). LSU and SSU sequence data were assembled using the alignment program BioEdit (Hall 1999) and ClustalX (Kohli \& Bachhawat 2003). Multiple sequence alignments were generated with MAFFT v. 7 (http:// mafft.cbrc.jp/alignment/server/index.html). The alignments are uploaded in TreeBASE (www.treebase.org/treebase-web/home.html) under ID 22740 for LSU-SSU alignment. Alignment was manually improved to achieve the maximum alignment and to minimize gaps with BioEdit. The file formats were converted in CIPRES Science Gateway (https://www.phylo.org/). The maximum likelihood analyses were performed in RAxML 7.4.2 Black Box (https://www.phylo.org/, Stamatakis 2006, Stamatakis et al. 2008). The final ML search was conducted using the GTRGAMMA + I model. All free model parameters were estimated by RAxML with ML estimates of 25 per site rate categories. The MrModeltest 2.2 was used to perform the model of evolution (Nylander et al. 2008). The phylogenetic analyses were performed for Bayesian inference in MrBayes v. 3.2.1 (Ronquist et al. 2012). Markov chain Monte Carlo (MCMC) sampling in MrBayes v.3.2.2 (Ronquist et al. 2012) was used to determine the posterior probabilities (PP) (Rannala \& Yang 1996, Zhaxybayeva \& Gogarten 2002). Six simultaneous Markov chains were run for 1000000 generations and trees were sampled every 100th generation. Phylogenetic trees were viewed and arranged using FigTree v1.4.0. 


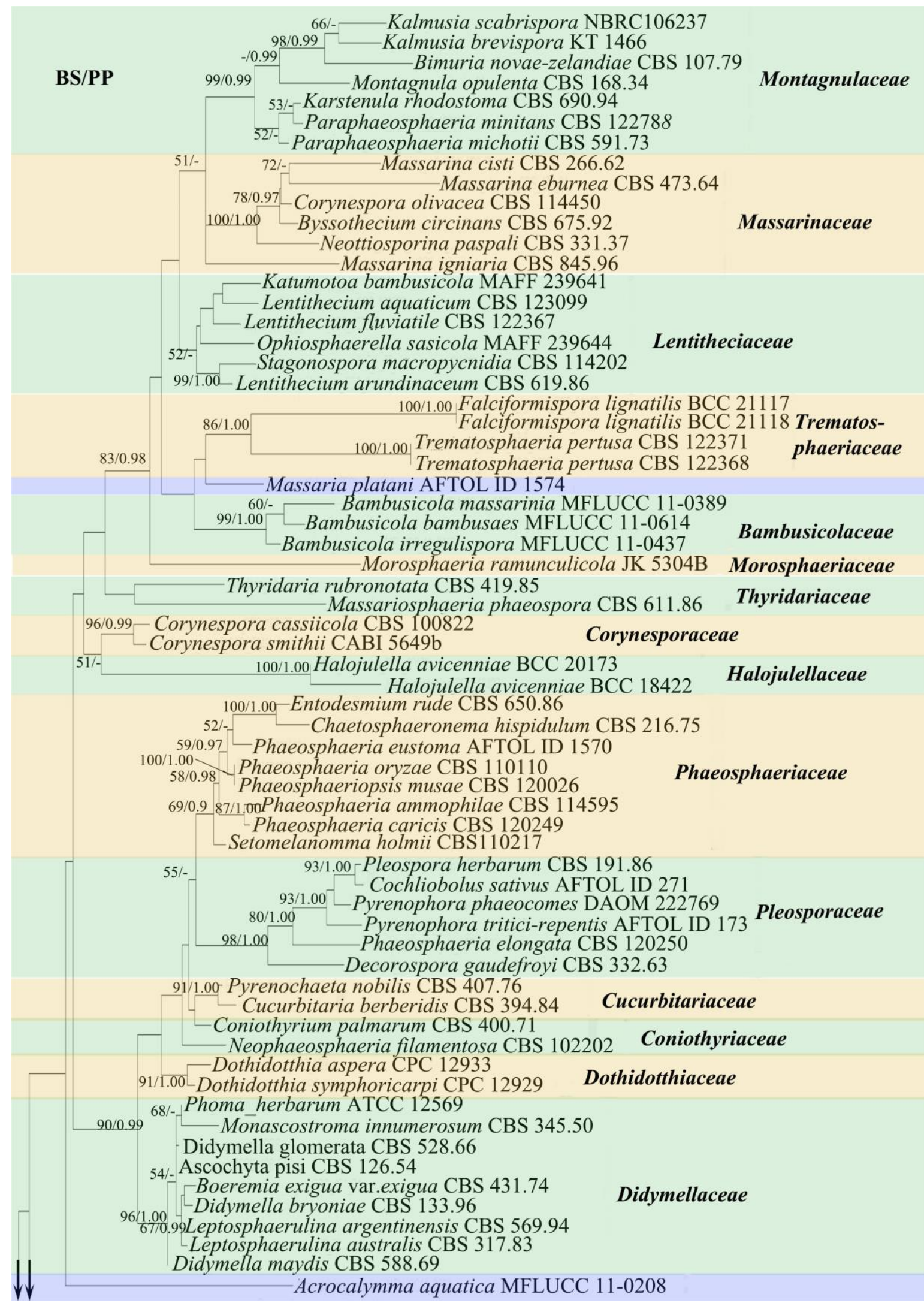

Figure 1 - RAxML tree based on analysis of a combined SSU and LSU nrDNA dataset. Bootstrap support values for maximum likelihood (ML) higher than 50\% ML (left) and Bayesian posterior probabilities equal to, or higher than $0.95 \mathrm{PP}$ (right) were marked above the nodes. The values below the nodes are Bayesian posterior probabilities above 0.95. Hyphen ("-") means a value lower than $50 \%$ (BS) or $0.95(\mathrm{PP})$. The strains numbers are noted after the species names. The tree was rooted to Hysterium angustaum (CBS 236.34, CBS 123334). 


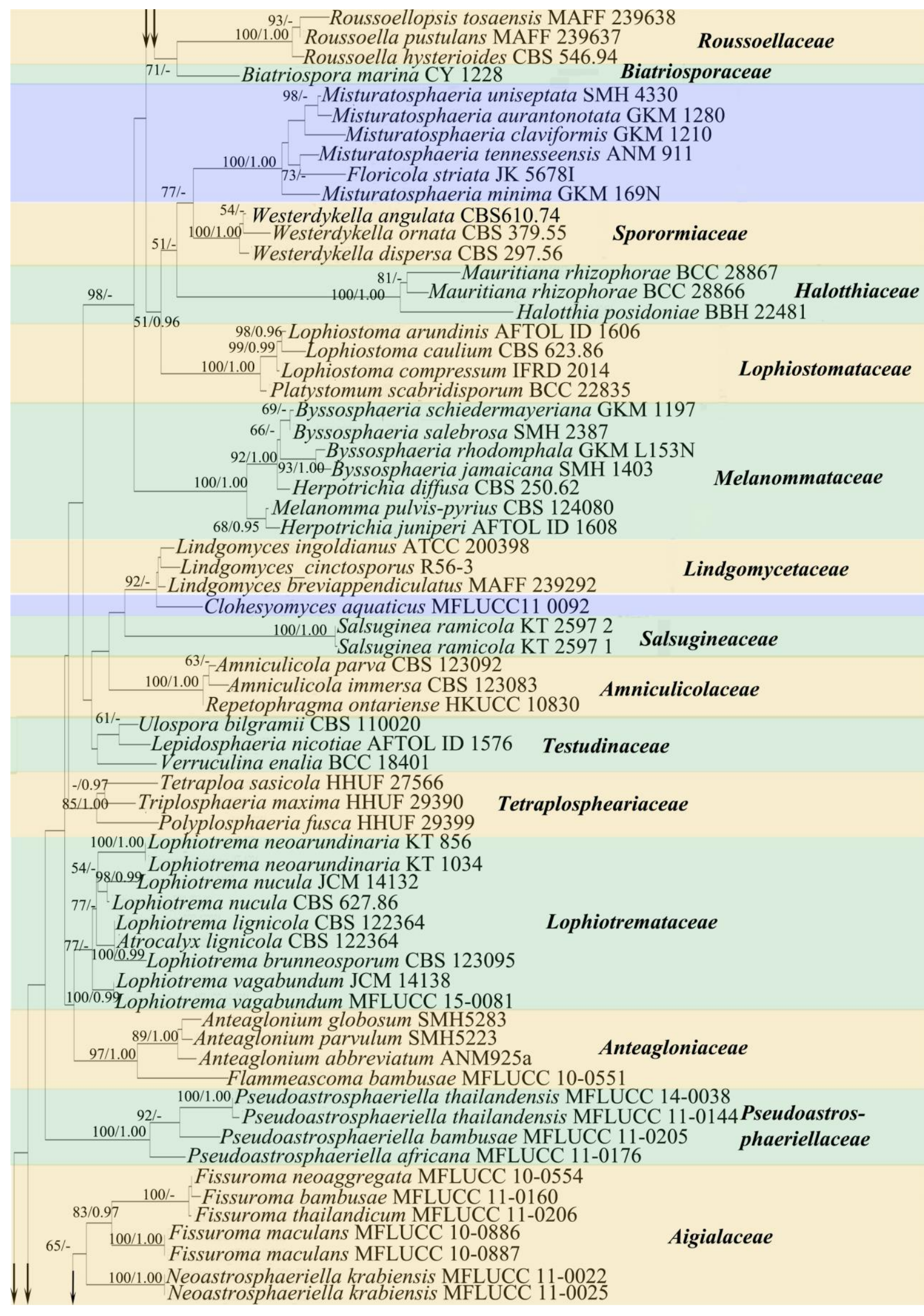

Figure 1 - Continued. 


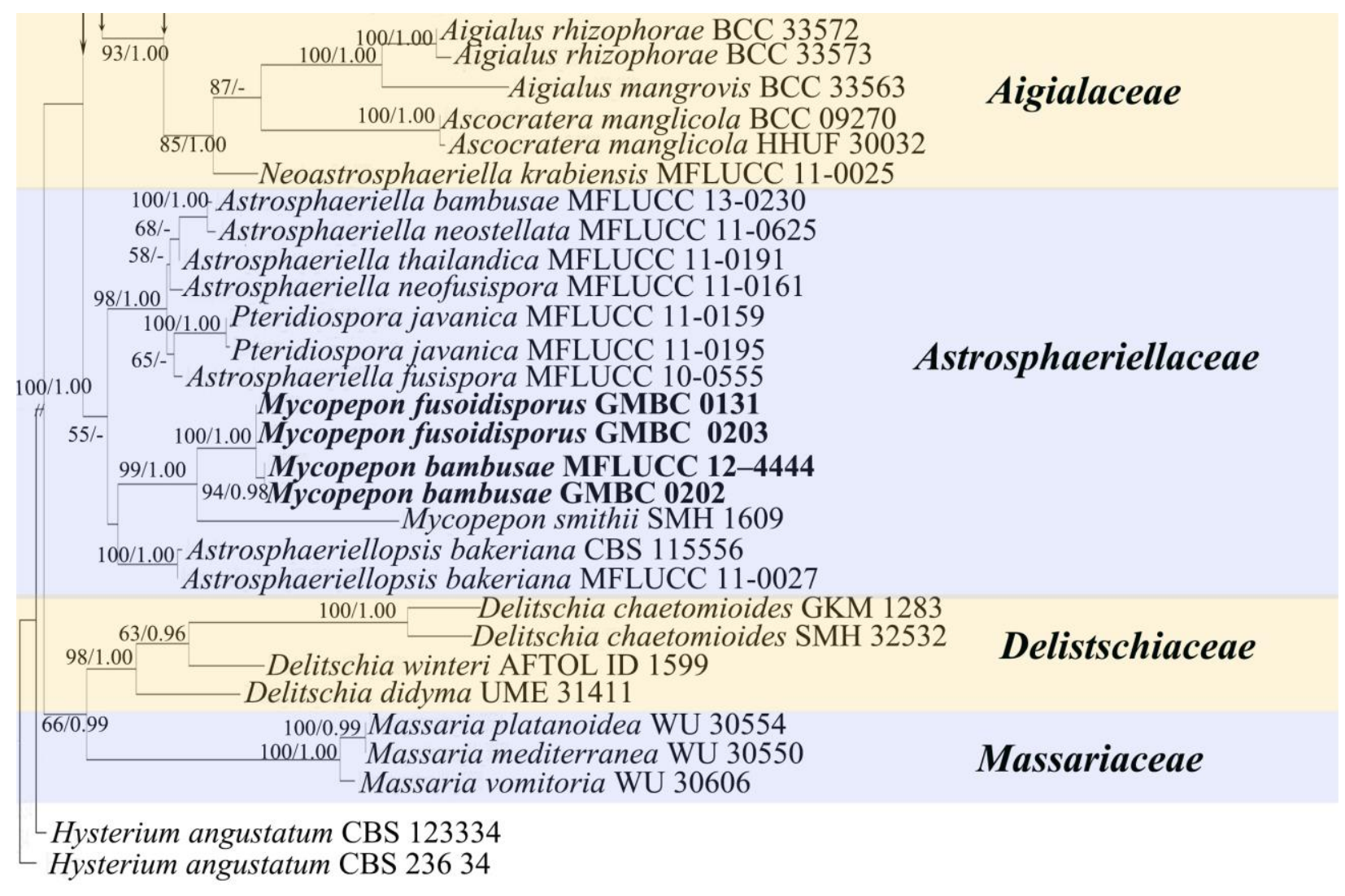

Figure 1 - Continued.

\section{Results}

ITS rDNA sequences of four strains were obtained. Initial BLAST searches suggested that our strains have high homology with Mycopepon smithii (SMH 1609). LSU and SSU regions were sequenced to identify these species and their classification status.

\section{Phylogenetic analyses}

A phylogenetic study using two combined loci (LSU, SSU) was conducted. All characters and gaps have equal weight. A total of 159 taxa were included in the analysis. Total length of the alignment was 1693 characters, in which 190 of those characters were variable, 1031 characters were constant, and 472 parsimony-informative characters. The final RAxML tree is shown in Figure 1, with the final ML optimization likelihood value of -19570.276304. RAxML and Bayesian analysis of the combined dataset resulted in phylogenetic reconstructions with largely similar topologies, and the RAxML tree is shown in Fig. 1. Our taxa gathered together with $M$. smithi. All Mycopepon species formed a well-supported clade (99/1.00), which is phylogenetically fell in the family Astrosphaeriellaceae.

\section{Taxonomy}

Mycopepon mexicanus (F. San Martín) Q.R. Li \& K.D. Hyde, stat. nov.

$\equiv$ Mycopepon smithii var. mexicanum F. San Martín, Acta Bot. Mexicana 35: 10 (1996)

Index Fungorum number: IF416160; Facesoffungi number: FoF 04689

Etymology - In reference to the location, Mexico.

Notes - See Gonzalez (1996) for descriptions. The variety mexicanum of Mycopepon smithi collected in Mexico was described by Gonzalez (1996). This taxon has larger ascospores (60-84 $\times$ 14-16 $\mu \mathrm{m}$ ) than those of Mycopepon smithii (Gonzalez 1996, Smith 1893). Because of the noticeable differences between these two taxa, we propose this variety be raised to a new species here. The holotype, San Martín 869B, was deposited at Instituto Tecnológico de Ciudad Victoria 
(ITCV).

Mycopepon bambusae Q.R. Li \& K.D. Hyde, sp. nov.

Fig. 2

Index Fungorum number -IF554787; Facesoffungi number -FoF 04601

Etymology - In reference to the host bamboo.

Saprobes on rotting bamboo, forming on the host surface. Sexual morph: Ascostromata 0.5$0.8 \mathrm{~mm}$ long $\times 0.3-0.5 \mathrm{~mm}$ high, scattered or clustered, superficial on host tissue, oval, with long central beak (1-1.5 mm long), black, comprising 3-6 pseudothecia. Ascomata 320-530 $\mu \mathrm{m}$ diam., sphaerical, black, carbonaceous, papillae eccentric, long, fusing to form a common central papilla (beak). Hamathecium of 1-1.5 $\mu \mathrm{m}$ wide, long, cellular, numerous, septate, branching, pseudoparaphyses Asci 161.5-219.5 × 14.5-20.5 $\mathrm{m}(184 \times 17.5 \mu \mathrm{m}, \mathrm{n}=20), 8$-spored, bitunicate, cylindric-clavate, pedicellate, apically rounded, apex not bluing in Melzer's reagent. Ascospores $45-61.5 \times 6.5-8.5 \mu \mathrm{m}(52.5 \times 7.5 \mu \mathrm{m}, \mathrm{n}=30)$, tetra-seriate or partially overlapping, fusiform, brown to dark brown, 3- septa, slightly constricted at the central septum, rough-walled with small guttules, with broadly rounded ends, lacking sheaths or appendages. Asexual morph: Undetermined.

Culture characteristics - Colonies growing on PDA (Fig. 3 A, B, E, F), rather slow-growing, reached to $2 \mathrm{~cm}$ diam. in 4 weeks at $25{ }^{\circ} \mathrm{C}$. Mycelium superficial, felty, gray at first and finally become to black, reverse of cultures black, tight, edge undulate.

Distribution - Guizhou Province, China

Material examined - CHINA, Guizhou Province, Miao and Dong Autonomous Prefecture Leishan County, Leigongshan National Nature Reserve ( $\left.26^{\circ} 22^{\prime} 12^{\prime \prime} \mathrm{N}, 108^{\circ} 11^{\prime} 47^{\prime \prime} \mathrm{E}\right)$, on dead bamboo rhizome, 3 February 2012, Q. R. Li, LGS 20 (HKAS 87823, holotype); living cultures MFLUCC 12-4444).

Other material examined - CHINA, Guizhou Province, Qiannan Buyi and Miao Autonomous Prefecture $\left(25^{\circ} 12^{\prime} 52^{\prime \prime} \mathrm{N}, 107^{\circ} 5^{\prime}\right.$ 57" E), August 2017, Q.R. Li, LGS113 (GMB0202, HKAS100934).

GenBank accession numbers: LGS20 MH049450 (SSU), MH049442 (LSU); GMB0202 SSU MH049453, MH049445 (LSU).

Table 1 Synopsis of Mycopepon species.

\begin{tabular}{|c|c|c|c|c|c|}
\hline Taxon & Ascostromata & Ascomata & Asci & Ascospores & Reference \\
\hline $\begin{array}{l}M . \\
\text { mexicanus }\end{array}$ & $\begin{array}{l}0.7-1.2 \mathrm{~mm} \text { diam., } 2- \\
6 \text { ascomata }\end{array}$ & Globose & $\begin{array}{l}194-246 \\
\times \quad 25-32 \\
\mu \mathrm{m}\end{array}$ & $\begin{array}{l}60-84 \times 14-16 \mu \mathrm{m}, \text { fusoid, deep } \\
\text { brown, } 3 \text {-septate, two end cells } \\
\text { small and paler. }\end{array}$ & $\begin{array}{l}\text { Gonzalez } \\
\text { (1996) }\end{array}$ \\
\hline M. smithii & $\begin{array}{l}1-1.5 \mathrm{~mm} \text { diam., } 4-8 \\
\text { ascomata }\end{array}$ & $\begin{array}{l}\text { Ovate, } 1 / 3 \mathrm{~mm} \\
\text { diam. }\end{array}$ & Not seen & $\begin{array}{l}52-62 \times 10-14 \mu \mathrm{m} \text {, inequilateral } \\
\text { ellipsoid, brown, } 3 \text {-septate, with } \\
\text { sharp ends. }\end{array}$ & $\begin{array}{l}\text { Smith } \\
(1893)\end{array}$ \\
\hline $\begin{array}{l}\text { M. } \\
\text { bambusae }\end{array}$ & $\begin{array}{l}0.5-0.8 \mathrm{~mm} \text { long } \times \\
0.3-0.5 \mathrm{~mm} \text { high, } 3-6 \\
\text { ascomata }\end{array}$ & $\begin{array}{l}\text { Sphaerical, 320- } \\
530 \mu \mathrm{m} \text { diam. }\end{array}$ & $\begin{array}{l}161.5- \\
219.5 \times \\
14.5-20.5 \\
\mu \mathrm{m}\end{array}$ & $\begin{array}{l}45-61.5 \times 6.5-8.5 \mu \mathrm{m} \text {, fusiform, } \\
\text { brown to dark brown, } 3 \text {-septate, } \\
\text { with broadly rounded ends. }\end{array}$ & This study \\
\hline $\begin{array}{l}\text { M. } \\
\text { fusoidispora }\end{array}$ & $\begin{array}{l}0.6-0.8 \mathrm{~mm} \text { long } \times \\
0.3-0.5 \mathrm{~mm} \text { high, } 2-8 \\
\text { ascomata }\end{array}$ & $\begin{array}{l}\text { Sphaerical, } 310- \\
500 \mu \mathrm{m} \text { diam. }\end{array}$ & $\begin{array}{l}178-223 \\
\times 31.5-42 \\
\mu \mathrm{m}\end{array}$ & $\begin{array}{l}45.5-57.5 \times 11.5-23.5 \mu \mathrm{m} \text {, } \\
\text { fusiform, brown to dark brown, } 1- \\
\text { septate, occasional } 3 \text {-septate, with } \\
\text { broadly rounded end and a } \\
\text { slightly flattened one. }\end{array}$ & This study \\
\hline $\begin{array}{l}\text { M. } \\
\text { guianensis }\end{array}$ & $\begin{array}{l}0.9-1.1 \mathrm{~mm} \text { diam. } \times \\
0.8-0.97 \mathrm{~mm} \text { high, } 3- \\
5 \text { ascomata }\end{array}$ & $\begin{array}{l}\text { Globose to } \\
\text { subglobose } 360- \\
660 \mu \mathrm{m} \text { high, } 300- \\
480 \mu \mathrm{m} \text { diam., }\end{array}$ & $\begin{array}{l}205-240 \\
\times \quad 28-38 \\
\mu \mathrm{m}\end{array}$ & $\begin{array}{l}58-75 \times 13-17 \mu \mathrm{m} \text {, fusiform, } \\
\text { brown to dark brown, } 1 \text {-septate, } \\
\text { occasional 3- septate, ends cells } \\
\text { paler }\end{array}$ & $\begin{array}{l}\text { Doilom et } \\
\text { al. } 2018\end{array}$ \\
\hline
\end{tabular}

Notes - Mycopepon bambusae is similar with M. smithii and M. mexicanus (Table 1). However, M. smithii has wider ascospores $(52-62 \times 10-14 \mu \mathrm{m})$ with small and paler ends (Smith 1893). Mycopepon bambusae differs from M. mexicanus $(60-84 \times 14-16 \mu \mathrm{m})$ by its smaller ascospores (Gonzalez 1996). 

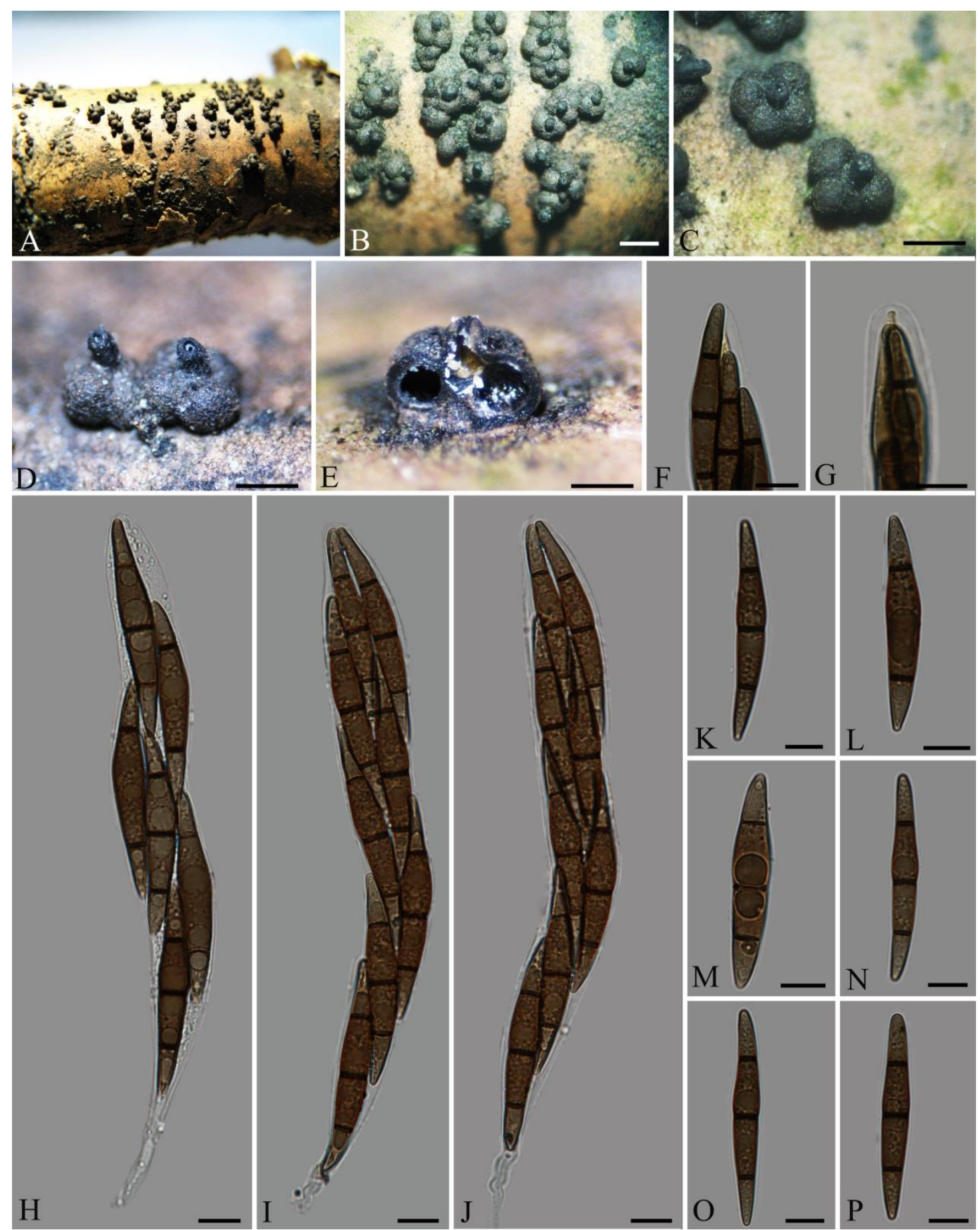

Figure 2 - Mycopepon bambusae (HKAS 87823, holotype) A Fresh material. B-D Stromata on the surface of host. E Section of ascostroma. F, G Ascus apex (stained in Melzer's reagent). $\mathrm{H}-\mathrm{J}$ Mature asci with ascospores. K-P Ascospores. Scale bars: $\mathrm{B}-\mathrm{E}=200 \mu \mathrm{m}$. F-P $=10 \mu \mathrm{m}$.

Mycopepon fusoidisporus Q.R. Li \& K.D. Hyde, sp. nov.

Fig. 4

Index Fungorum number: IF554788; Facesoffungi number: FoF 04602

Etymology - In reference to the fusoid ascospores.

Saprobic on initial rotting bamboo rhizome, forming on the host surface. Sexual morph: Ascostromata $0.6-0.8 \mathrm{~mm}$ long $\times 0.3-0.5 \mathrm{~mm}$ high, superficial, scattered or clustered, superficial on host tissue, oval, with long central beak $(0.3-0.5 \mathrm{~mm}$ long $\mathrm{mm}$ long), black, comprising 2-8 pseudothecia. Ascomata 310-500 $\mu \mathrm{m}$ diam., sphaerical, black, carbonaceous, papillae eccentric, long, fusing to form a common central papilla (beak). Hamathecium comprising 1-1.5 $\mu \mathrm{m}$ wide, long cellular, numerous, septate, branching, pseudoparaphyses. Asci 178-223 × 31.5-42 $\mu \mathrm{m}(203.5$ 
$\times 35.5 \mu \mathrm{m}, \mathrm{n}=30$ ), 8 -spored, bitunicate, cylindric-clavate, pedicellate, apically rounded. Ascus apex well-developed ocular chamber, not blueing in Melzer's reagent. Ascospores 45.5-57.5 × 11.5$23.5 \mu \mathrm{m}(51 \times 17 \mu \mathrm{m}, \mathrm{n}=30)$, tetra-seriate or partially overlapping, brown to dark brown, 1-septate, occasional 3- septate, fusiform, smooth-walled, slightly thicker at the center, with broadly rounded end and a slightly flattened one, lacking a sheath and appendages. Asexual morph: Undetermined.

Culture characteristics - Colonies growing on PDA (Fig. 3 C, D, G, H), rather slow-growing, reached to $2.5 \mathrm{~cm}$ diam. in 4 weeks at $25{ }^{\circ} \mathrm{C}$. Mycelium superficial, felty, gray at first and finally become to black, reverse of cultures black, tight, edge undulate.

Distribution - Known to inhabit dead bamboo, Guizhou Province, China.

Material examined - CHINA, Guizhou Province, Qiandongnan Miao and Dong Autonomous Prefecture, Maolan National Nature Reserve $\left(25^{\circ} 18^{\prime} 08^{\prime \prime} \mathrm{N}, 108^{\circ} 04^{\prime} 25^{\prime \prime} \mathrm{E}\right)$, saprobic on the rhizome of bamboo, August 2016, Q.R. Li, ML056 (GMB0131, holotype; HKAS100936, isotype; living cultures GMBC0131)

Other material examined - CHINA, Guizhou Province, Qiannan Buyi and Miao Autonomous Prefecture, August 2017, Q.R. Li, LGS114 (HKAS100935, GMB0203, paratypes).

GenBank accession numbers: GMB0131 MH049451 (SSU), MH049443 (LSU); GMB0203, MH049452 (SSU), MH049444 (LSU).

Notes - Mycopepon fusoidisporus differs from M. smithii and M. bambusae by its wider and 1-septate ascospores. Mycopepon smithii has long spindle-shaped, 3-septate ascospores (30-65 $\times$ 6-16 $\mu \mathrm{m}$ ) (Smith 1893, Boise 1987). Moreover, M. fusoidisporus has short beaks (versus long central papilla) than that of M. bambusae.

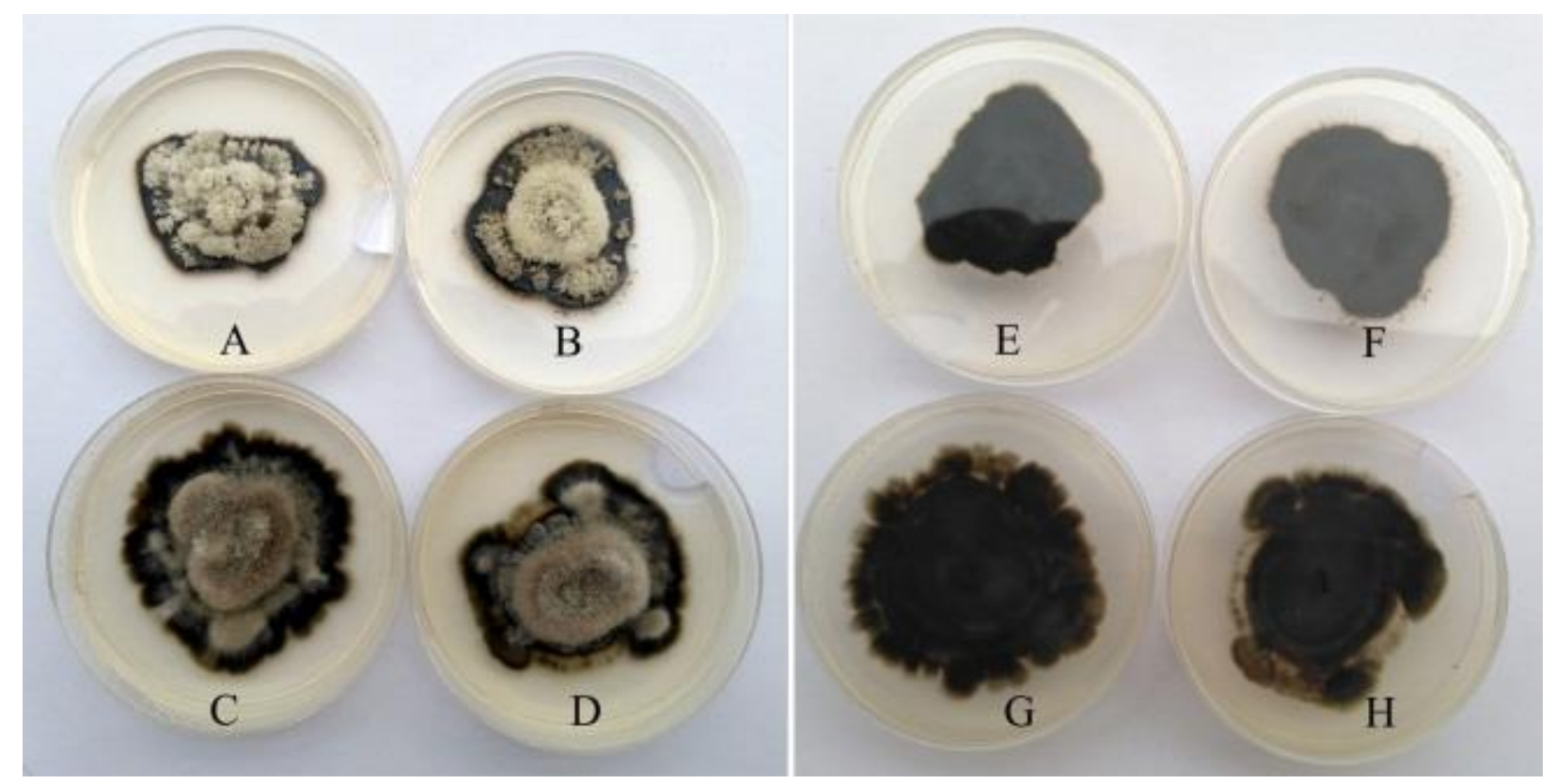

Figure 3 - Colonies on PDA after 5 week. (A GMB0202. B LGS20. C GMB0203. D GMB0131. E GMB0202. F LGS20. G GMB0203. H GMB0131.)

\section{Discussion}

Mycopepon guianensis was introduced as the type species of Mycopepon (Boise 1987). Boise (1994) reexamined the specimen of Pseudovalsa smithii Ellis \& Everh. and found that these two names are synonymous: hence, Mycopepon smithii (Ellis \& Everh.) Boise (synonym: P. smithii Ellis \& Everh., M. guianensis Boise) was proposed. The variety mexicanum of Mycopepon smithi was found and identified by Gonzalez (1996). Currently, M. smithii, M. guianensis and M. smithii var. mexicanum were considered to be synonyms of M. smithii (Index Fungorum 2018). However, $M$. mexicanus ( $\equiv M$. smithii var. mexicanum) has larger ascospores than those of $M$. smithii (Table 1). Two new species collected in China, were identified and are illustrated in this paper. The 
hosts of Mycopepon have a wide diversity. Mycopepon guianensis (current name: M. smithi) was found on decorticated wood, Mycopepon mexicanus ( $\equiv$ M. smithii var. mexicanum) was discovered on wood lacking bark in a high perennifolia forest, while the two species described herein were from bamboo. Mycopepon smithii and M. guianensis do not have the same characters (see Table 1), particularly the dimensions of the ascospores and may not be the same taxa. Fresh collections are needed.

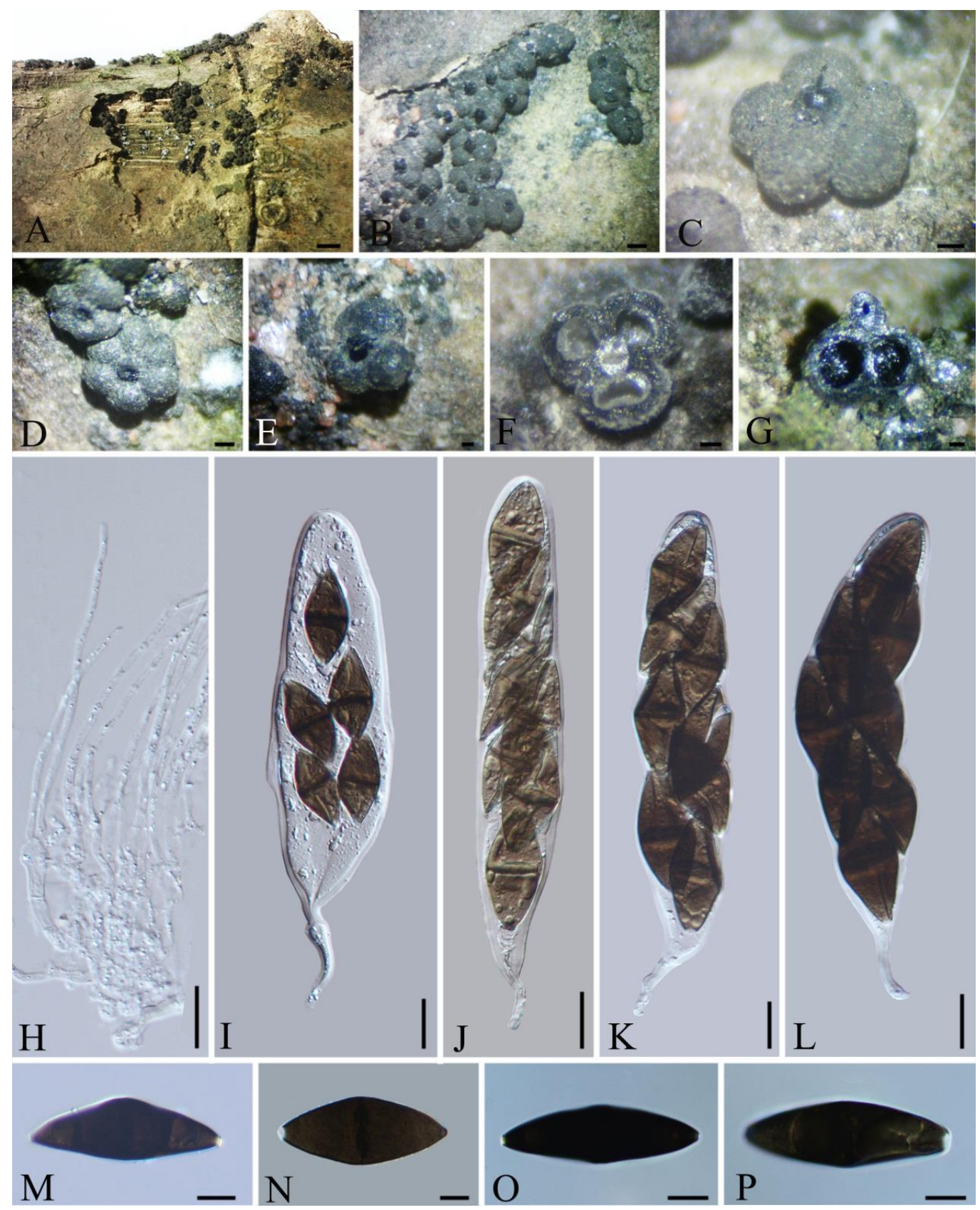

Figure 4 - Mycopepon fusoidisporus (GMB0131, holotype) A Fresh material. B-E Ascostromata on surface of host. F, G Section of ascostroma. H Paraphyses. I-L Asci with ascospores. M-P Ascospores. Scale bars: $A=2 \mathrm{~mm} . \mathrm{B}=0.5 \mathrm{~mm} . \mathrm{C}-\mathrm{G}=100 \mu \mathrm{m}$. H-L $=20 \mu \mathrm{m} . \mathrm{M}-\mathrm{P}=10 \mu \mathrm{m}$.

Mycopepon was introduced and could not be assigned to any family in Pleosporales (Boise 1987). The habit of Mycopepon is similar with those of Diaporthales, Diatrypaceae and members of Massariaceae sensu Barr (Eriksson \& Hawksworth 1986). Eriksson \& Hawksworth (1987) considered the genus should be placed in Melanommataceae, especially since the pseudoparaphyses were trabeculae (Liew et al. 2000). LSU and SSU sequence data for M. smithii (SMH 1609) 
marked as a species of Dothideomycetes were used to study the placement in Sordariales (Huhndorf et al. 2004). Mycopepon smithii (SMH 1609) showed a close relationship with Berkleasmium crunisia Pinnoi and B. typhae Somrith. \& E.B.G. Jones, and was placed in Pleosporales genera incertae sedis (Pinnoi et al. 2007). In this paper, our strains cluster with $M$. smithii (SMH 1609). Mycopepon species were close to Astrosphaeriellopsis bakeriana within the Pleosporales. Astrosphaeriellopsis bakeriana ( $\equiv$ Astrosphaeriella bakeriana) formed a single clade was excluded from the genus Astrosphaeriella, and was accommodated in a new genus Astrosphaeriellopsis in the Pleosporales genera incertae sedis (Phookamsak et al. 2015). Astrosphaeriellaceae was introduced to accommodate Astrosphaeriella and Pteridiospora in Pleosporales by Phookamsak et al. (2015). Wanasinghe et al. (2018) suggested that Astrosphaeriellopsis and Astrosphaeriella should be assigned to Astrosphaeriellaceae. Mycopepon is similar to Astrosphaeriellopsis and Astrosphaeriella in its superficial ascostromata and trabeculate pseudoparaphyses (Liew et al. 2000), but differs from by its ascostromata comprising 2-8 pseudothecia. However, all of Mycopepon, Astrosphaeriellopsis and Astrosphaeriella have superficial carbonaceous ascostromata, trabeculate pseudoparaphyses and fusoid ascospores with septa. Therefore, Mycopepon falls in Astrosphaeriellaceae of Pleosporales in this paper.

\section{Acknowledgements}

This work were funded by the fund of high level innovation talents [No. 2015-4029], the fund of innovation team of Guizhou province [No. 2015-4025], the fund of innovated team of the education department of Guizhou province [No. 2014-31] and the program for new century excellent talents in university[No. NCET-13-0747], the fund of Guizhou provincial traditional Chinese medicine administration project QZYY-2016-097, doctoral staring foundation of Guizhou medical university (YT2017-13) and Guiyang science and technology planning project No. [2017]30-19.

\section{References}

Boise JR. 1987 - Mycopepon, a new ascomycete genus. Systema Ascomycetum 6, 167-170.

Boise JR. 1994 - Pseudovalsa smithii is an earlier name for Mycopepon guianensis. Mycotaxon 52, 303.

Dai DQ, Phookamsak R, Wijayawardene NN, Li WJ et al. 2016 - Bambusicolous fungi. Fungal Diversity $82,1-105$.

Doilom M, Hyde KD, Phookamsak R, Dai DQ et al. 2018 - Mycosphere Notes 225-274: Types and other specimens of some genera of Ascomycota. Mycosphere, in press.

Eriksson O, Hawksworth DL. 1986 - Notes on ascomycete systematics. Nos 1-224. Systema Ascomycetum 5, 113-174.

Eriksson O, Hawksworth DL. 1987 - Notes on ascomycete systematics. Systema Ascomycetum 6, 111-165.

Hall TA. 1999 - BioEdit: a user-friendly biological sequence alignment editor and analysis program for Windows 95/98/NT. Nucleic Acids Symposium Series 41, 95-98.

Huhndorf SM, Miller AN, Fernández FA. 2004 - Molecular systematics of the Sordariales: the order and the family Lasiosphaeriaceae redefined. Mycologia 96, 368-387.

Hyde KD, Jones EBG, Liu JK, Ariyawansa H et al. 2013 - Families of Dothideomycetes. Fungal Diversity 63, 1-313.

Hyde KD, Zhou DQ, Dalisay T. 2002 - Bambusicolous fungi: a review. Fungal Diversity 9: 1-14.

Index Fungorum. 2018 - Available from: http://www.indexfungorum.org/Names/Names.asp (accessed June 2018).

Gonzalez FSM. 1996 - Una nueva varieda de Mycopepon smithii (Ascomycetes, Pleosporales). Acta Botánica Mexicana 35, 9-12.

Kohli DK, Bachhawat AK. 2003 - CLOURE: Clustal Output Reformatter, a program for reformatting CLUSTALX/ CLUSTALWoutputs for use in SNP analysis and molecular systematics. Nucleic Acids Research 31, 3501-3502. 
Li QR, Kang JC, Hyde KD. 2015 - Two new species of the genus Collodiscula (Xylariaceae) from China. Mycological Progress 14, 52.

Liew ECY, Aptroot A, Hyde KD. 2000 - Phylogenetic significance of the pseudoparaphyses in Loculoascomycete taxonomy. Molecular Phylogeny \& Evolution 16, 392-402.

Liu JK, Lu YZ, Cheewangkoon R, To-Anun C. 2018 - Phylogeny and morphology of Helicotubeufia gen. nov., with three new species in Tubeufiaceae from aquatic habitats. Mycosphere 9(3), 495-509.

Nylander JAA, Wilgenbusch JC, Warren DL, Swofford DL. 2008 - AWTY (are we there yet?): a system for graphical exploration of MCMC convergence in Bayesian phylogenetics. Bioinformatics 24, 581-583

Phookamsak R, Liu JK, McKenzie EHC, Manamgoda DS et al. 2014 - Revision of Phaeosphaeriaceae. Fungal Diversity 68, 159-238.

Phookamsak R, Norphanphoun C, Tanaka K, Dai DQ et al. 2015 - Towards a natural classification of Astrosphaeriella-like species; introducing Astrosphaeriellaceae, and Pseudoastrosphaeriellaceae, fam. nov. and Astrosphaeriellopsis, gen. nov. Fungal Diversity 74, 143-197.

Pinnoi A, Jeewon R, Sakayaroj J, Hyde KD et al. 2007 - Berkleasmium crunisia sp. nov. and its phylogenetic affinities to the Pleosporales based on $18 \mathrm{~S}$ and $28 \mathrm{~S}$ rDNA sequence analyses. Mycologia 99, 378.

Rannala B, Yang Z. 1996 - Probability distribution of molecular evolutionary trees: a new method of phylogenetic inference. Journal of Molecular Evolution 43, 304-311.

Ronquist F, Teslenko M, Vander MP. 2012 - MrBayes 3.2: efficient Bayesian phylogenetic inference and model choice across a large model space. Systematic Biology 61, 539-542.

Smith CL. 1893 - Some Central American pyrenomycetes. Natural History Bulletin. 2: 404.

Stamatakis A. 2006 - RAxML-VI-HPC: maximum likelihood-based phylogenetic analyses with thousands of taxa and mixed models. Bioinformatics 22, 2688-2690.

Stamatakis A, Hoover P, Rougemont J. 2008 - A rapid bootstrap algorithm for the RAxML webservers. Systematic Biology 75, 758-771.

Su H, Li QR, Kang JC, Wen TC et al. 2016 - Rosellinia convexa, sp. nov. (Xylariales, Pezizomycotina) from China. Mycoscience 57, 164-170.

Vilgalys R, Hester M. 1990 - Rapid genetic identification and mapping of enzymatically amplified ribosomal DNA from several Cryptococcus species. Journal of Bacteriology 172, 4238-4246.

Wanasinghe DN, Jeewon R, Jones EBG, Boonmee S et al. 2018 - Novel palmicolous taxa within Pleosporales: multigene phylogeny and taxonomic circumscription. Mycological Progress **, $1-20$.

White T, Bruns T, Lee S, Taylor J. 1990 - Amplification and direct sequencing of fungal ribosomal RNA genes for phylogenetics. PCR Protocols: A Guide to Methods and Applications 18, 315-322.

Wijayawardene NN, Crous PW, Kirk PM, Hawksworth D et al. 2014 - Naming and outline of Dothideomycetes-2014 including proposals for the protection or suppression of generic names. Fungal Diversity 69, 1-55.

Wijayawardene NN, Hyde KD, Bhat DJ, Goonasekara I. 2015 - Additions to brown spored coelomycetous taxa in Massarinae, Pleosporales: Introducing Phragmocamarosporium gen. nov. and Suttonomyces gen. nov.. Cryptogamie Mycologie 36, 213-224.

Wijayawardene NN, Hyde KD, Rajeshkumar KC, Hawksworth DL et al. 2017 - Notes for genera: Ascomycota. Fungal Diversity 86, 1-594.

Wijayawardene NN, Hyde KD, Lumbsch HT, Liu JK et al. 2018 - Outline of Ascomycota: 2017. Fungal Diversity 88, 167-263.

Wijayawardene DNN, Song Y, Bhat DJ, McKenzie EHC et al. 2013 - Wojnowicia viburni sp. nov. from China and its phylogenetic placement. Sydowia 65, 181-190

Zhaxybayeva O, Gogarten JP. 2002 - Bootstrap, Bayesian probability and maximum likelihood mapping: exploring new tools for comparative genome analyses. BMC Genomics 3, 4 . 